\title{
Opracowanie metod wprowadzania nanorurek węglowych do jeziorka ciekłego metalu
}

\section{Development of methods of carbon nanotubes input to weld pool}

\section{Streszczenie}

Niezwykłe właściwości nanorurek węglowych stwarzają perspektywy do ich wykorzystania w wielu dziedzinach nauki i techniki. W obszarze inżynierii materiałowej główne badania $z$ udziałem nanorurek węglowych obejmują wytwarzanie materiałów kompozytowych. Kompozyty o osnowie metalowej wzmacniane nanorurkami węglowymi MM-CNT (ang. metal matrix - carbon nanotube composites) mogą być projektowane w celu uzyskania materiału o małej gęstości, wysokiej wytrzymałości, niskim współczynniku rozszerzalności cieplnej oraz wysokiej przewodności cieplnej. Lekkie i wytrzymałe materiały konstrukcyjne stanowią podstawę przyszłych, efektywnych energetycznie, a tym samym ekologicznych i ekonomicznych rozwiązań technologicznych przemysłu lotniczego i samochodowego.

W artykule przedstawiono przebieg badań nad opracowaniem metod wprowadzania nanorurek węglowych do jeziorka ciekłego metalu w celu wytworzenia eksperymentalnych materiałów kompozytowych MM-CNT oraz określenia wpływu CNTs na strukturę i właściwości stali.

Zaproponowane procedury, wykorzystujące techniki spawalnicze, stanowią nową, obok odlewania i infiltracji porowatego „performu”, metodę wytwarzania MM-CNT w stanie ciekłym. Przeprowadzona analiza struktury i właściwości uzyskanych obszarów przetopień stali austenitycznej potwierdza zasadność dalszych badań z wykorzystaniem nanorurek węglowych oraz innych metali i stopów o niskiej temperaturze topnienia.
Mgr inż. Marek Burda, dr inż. Tomasz Kik, dr hab. inż. Andrzej Gruszczyk, prof. PŚl. - Politechnika Śląska, Gliwice, dr inż. Krzysztof Kozioł - University of Cambridge, Wielka Brytania.

\section{Abstract}

Unusual properties of carbon nanotubes offer prospects for their use in many fields of science and technology. In the materials engineering major study involving carbon nanotubes includes production of composite materials. Metal matrix composites reinforced with carbon nanotubes MM-CNT (matrix metal - carbon nanotube composites) can be designed in order to obtain a material with low density, high strength, low coefficient of thermal expansion and high thermal conductivity. Lightweight and high-resistant construction materials are the basis for future energy efficient and thus the ecological and economical technology for aerospace and automotive industry.

The paper presents the research on the development of carbon nanotubes input methods to weld pool to form an experimental MM-CNT composite, and determine the impact of CNTs on the structure and properties of steel.

The proposed procedures with the use of welding techniques are a new, next to casting and infiltration of a porous „perform”, methods of producing MM-CNT in a liquid state. The analysis of the structure and properties of the weld penetration regions of austenitic stainless steel confirms the further research validity of using carbon nanotubes and other metals and alloys with low melting point.

\section{Wstęp}

Począwszy od 1993 r. stale wzrastająca liczba publikacji naukowych dotyczących kompozytów wzmacnianych CNTs koncentruje się wokół matryc polimerowych, 
podczas gdy ceramika i metale zyskują mniejszą uwagę [1, 2]. Ta sytuacja przypomina rozpoczęte kilka dekad wcześniej próby zastosowania mikrometrowych włókien węglowych w materiałach kompozytowych. Od momentu komercyjnego zastosowania kompozytów polimerowych wzmacnianych włóknami węglowymi minęło kilka lat do uzyskania pierwszych pozytywnych wyników w zakresie kompozytów o osnowie metalowej. Osnowy polimerowe zwykle charakteryzują się gorszymi, w porównaniu z metalami, właściwościami mechanicznymi, termicznymi, elektrycznymi czy też trybologicznymi. Wprowadzenie do takiej osnowy składnika o właściwościach kilka rzędów wyższych/ lepszych ułatwia uzyskanie umocnienia [3]. Sytuacja jest odmienna w przypadku metali bądź materiałów ceramicznych, gdzie ogólnie dobre właściwości osnowy utrudniają wykazanie korzyści płynących z wprowadzenia włókien. Wykorzystanie w kompozytach metalowych potencjalnie wysokich właściwości nanorurek węglowych, w szczególności mechanicznych, termicznych oraz elektrycznych, wiąże się z wieloma problemami, zwykle niewystępującymi przy kompozytach polimerowych [4]. Podstawowy problem to brak zwilżania nanorurek węglowych przez większość metali oraz wysoka temperatura towarzysząca procesom wytwarzania kompozytów MM-CNTs. Nanorurki mają bardzo dużą powierzchnię właściwą, dochodzącą do $200 \mathrm{~m}^{2} / \mathrm{g}$, co bezpośrednio wpływa na ich skłonność do aglome-

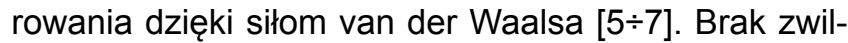
żania CNTs przez większość metali potęguje efekt tworzenia klastrów, a tym samym prowadzi do porowatości materiału kompozytowego. Trudność zapewnienia odpowiedniej dyspersji włókien w osnowie stanowi kolejną przeszkodę w dążeniu do pełnego wykorzystania potencjału nanorurek węglowych [1, 4, 8, 9]. Inne wyzwanie dotyczące produkcji kompozytów MM-CNTs wynika z konieczności zapewnienia chemicznej i strukturalnej stabilności nanorurek w metalowej osnowie. Wysoka temperatura i niejednokrotnie znaczne naprężenia towarzyszące produkcji MMC (ang. metal matrix composites) mogą być przyczyną defektów bądź całkowitego rozkładu CNTs w wyniku niekontrolowanej reakcji $[1,10]$.

Metody wytwarzania materiałów kompozytowych MM-CNTs można najogólniej podzielić na dwie grupy. Pierwsza obejmuje metody niewymagające nagrzania metalu do temperatury przekraczającej jego temperaturę topnienia, druga obejmuje procesy wymagające udziału fazy ciekłej.

Większość metod wytwarzania materiałów kompozytowych w stanie stałym jest oparta na technikach metalurgii proszków. Nanorurki węglowe mieszane są z proszkiem metalu, po czym następuje ich zagęszczanie w wysokiej lub niskiej temperaturze. Podstawową zaletą metalurgii proszków jest możliwość wytwarzania kompozytów o dowolnym składzie chemicznym ze względu na brak zależności od przemian fazowych, jak to ma miejsce $\mathrm{w}$ procesach wysokotemperaturowych (np. odlewaniu). Techniki metalurgii proszków znala- zły zastosowanie głównie do wytwarzania kompozytów

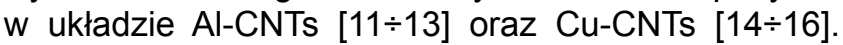
Inne analizowane osnowy to $\mathrm{Mg}$ [17], $\mathrm{Ni}$ [14], Ag [18], Sn [19], Ti [20] oraz ich stopy.

Metody wytwarzania materiałów kompozytowych w stanie ciekłym, ogólnie są dzielone na odlewanie i infiltrację, są znacznie mniej powszechne od metod metalurgii proszków. Ze względu na temperaturę topnienia osnowy koncentrują się głównie wokół $\mathrm{Al}, \mathrm{Mg}$ i ich stopów [21, 22]. Infiltracja jest techniką, w której ciekły metal lub stop infiltruje tkaninę z włókien nanorurkowych lub porowaty „perform” przygotowany na drodze metalurgii proszków [23]. W tym przypadku głównym problemem nie jest dyspersja nanorurek w ciekłym metalu, tak jak w procesach odlewania, lecz zapewnienie poprawnego wypełnienia porów.

Podstawową zaletą procesów wysokotemperaturowych jest łatwość formowania dużych wyrobów, przez co idealnie sprawdzają się w produkcji na masową skalę. Jednak wysoka temperatura procesów oraz szczególne właściwości fizykochemiczne nanorurek węglowych wiążą się z wyzwaniami wynikającymi z konieczności zapewnienia: odpowiedniej dyspersji nanorurek węglowych w ciekłym metalu lub stopie, stabilności strukturalnej nanorurek w ciekłym metalu lub stopie i stabilności chemicznej nanorurek w aktywnym metalu lub stopie. Brak zwilżania nanorurek węglowych przez większość metali wymaga odpowiedniej modyfikacji układu CNTs-metal. Jednym ze sposobów poprawy zwilżalności jest dodatek do analizowanej osnowy odpowiednich pierwiastków stopowych [24]. Rodzaj i ilość dodatków zwykle wymaga optymalizacji razem z parametrami konsolidacji, w celu zapewnienia pożądanych właściwości kompozytu wynikających z poprawnej strefy rozdziału faz, a z drugiej strony uniknięcia niekontrolowanej reakcji chemicznej mogącej doprowadzić do rozkładu CNTs.

Tylko nieliczne prace dotyczą wytwarzania materiałów kompozytowych w stanie ciekłym z wykorzystaniem technik spawalniczych. Istnieją więc przesłanki ku temu, by podjąć badania w tym zakresie i w zakresie zastosowania nanorurek węglowych jako modyfikatorów struktury i właściwości stali, metali oraz ich stopów. Celem niniejszych badań jest opracowanie metod wprowadzania nanorurek węglowych do jeziorka ciekłego metalu, dzięki czemu będzie możliwe wytworzenie eksperymentalnych materiałów kompozytowych MM-CNT oraz określenie wpływu CNTs na strukturę i właściwości stali.

\section{Przebieg badań}

Badano trzy metody wprowadzania nanorurek węglowych do jeziorka ciekłego metalu. Ich skuteczność przeanalizowano dla osnowy w postaci stali austenitycznej 1H18N9 (AISI 301, rys. 1, tabl. I) oraz procesów przetapiania GTA, mikroplazmowego i laserowego. W dwóch metodach wykorzystano komercyjnie 


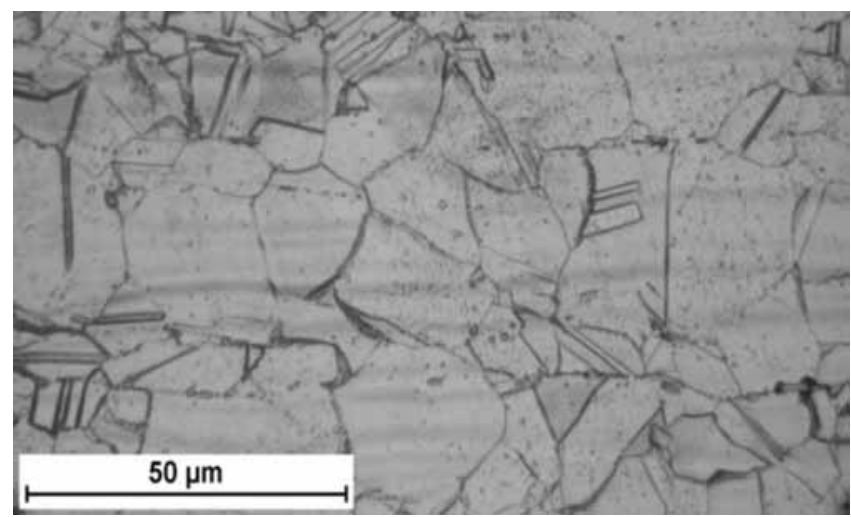

Rys. 1. Mikrostruktura stali $1 \mathrm{H} 18 \mathrm{~N} 9$ (AISI 301)

Fig. 1. Microstructure of 1H18N9 (AISI 301) steel

Tablica I. Skład chemiczny stali 1H18N9 (AISI 301)

Table I. Chemical composition of 1H18N9 (AISI 301) steel

\begin{tabular}{|c|c|c|c|c|c|c|c|c|}
\hline C & $\mathrm{Si}$ & $\mathrm{Mn}$ & $\mathrm{Cr}$ & $P$ & $S$ & $\mathrm{~N}$ & Mo & $\mathrm{Ni}$ \\
\hline 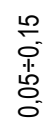 & O̊ & 오 & 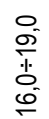 & $\begin{array}{l}\frac{8}{0} \\
0 \\
\text { Vi }\end{array}$ & 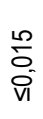 & $\begin{array}{l}\bar{\delta} \\
\text { vi }\end{array}$ & $\begin{array}{l}\infty \\
\stackrel{0}{0} \\
\text { vi }\end{array}$ & $\begin{array}{l}0 \\
0 \\
0 \\
0 \\
0 \\
0\end{array}$ \\
\hline
\end{tabular}
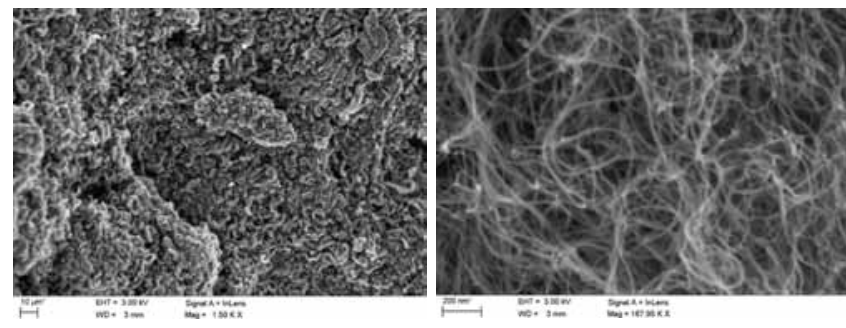

Rys. 2. Obraz SEM nanorurek węglowych NANOCYLTM NC7000

Fig. 2. The NANOCYLTM NC7000 carbon nanotubes SEM view

Tablica II. Parametry nanorurek węglowych NANOCYLTM NC7000 Table II. The NANOCYLTM NC7000 carbon nanotubes parameters

\begin{tabular}{|l|c|c|c|}
\hline Właściwość & Wartość & Jednostka & Metoda pomiaru \\
\hline Średnia średnica & 9,5 & $\mathrm{~nm}$ & TEM \\
\hline Średnia długość & 1,5 & $\mu \mathrm{m}$ & TEM \\
\hline Czystość nanorurek & 90 & $\%$ & TGA \\
\hline $\begin{array}{l}\text { Wtrącenia } \\
\text { tlenków metali }\end{array}$ & 10 & $\%$ & TGA \\
\hline $\begin{array}{l}\text { Obszar } \\
\text { powierzchniowy }\end{array}$ & $250 \div 300$ & $\mathrm{~m}^{2} / \mathrm{g}$ & BET \\
\hline
\end{tabular}

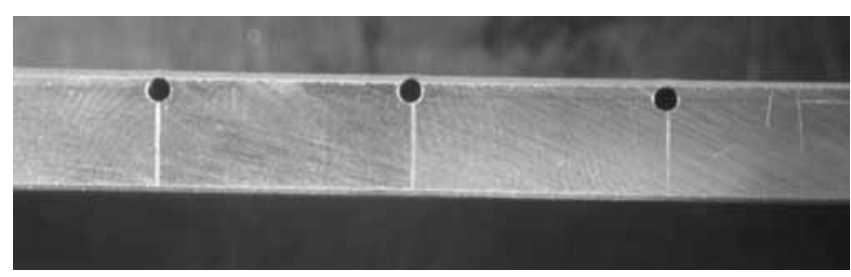

Rys. 3. Blacha ze stali austenitycznej $1 \mathrm{H} 18 \mathrm{~N} 9$ (AISI 301) przygotowana do wprowadzenia odpowiednich wsadów

Fig. 3. Austenitic stainless steel $1 \mathrm{H} 18 \mathrm{~N} 9$ (AISI 301) prepared to fill the holes with proper material dostępne, wielościenne nanorurki węglowe MWCNTs, wyprodukowane w procesie katalitycznego osadzania par węgla CCVD (ang. Catalic Chemical Vapor Deposition), NANOCYLTM NC7000 (rys. 2, tabl. II). W trzeciej metodzie wykorzystano wykonane w Department of Materials Science and Metallurgy, University of Cambridge, „dywaniki” stanowiące uporządkowane nanorurki węglowe o prostopadłej orientacji względem stalowego podłoża. W celu umożliwienia oceny wpływu odmiany węgla na właściwości i strukturę stali badania przedstawione w metodzie pierwszej powtórzono dla nawęglacza w formie Karburytu.

Procedura pierwsza. W materiale wejściowym (blacha ze stali austenitycznej 1H18N9) o wymiarach 155x60x7 mm wywiercono otwory o średnicy $1,3 \mathrm{~mm}$ w odległości ok 0,5 mm od powierzchni blachy (rys. 3). Do otworów wprowadzono nanorurki węglowe (CNTs), Karburyt (KR), żelazo (Fe) oraz proszki uzyskane dzięki zmieszaniu powyższych składników w młynie kulowym (tabl. III). Następnie zaślepiono otwory, aby uniknąc wysypania wsadu i dokonano przetopień metodą GTA (CASTOTIG 2002, EUTRONIC GAP 200, CASTOLIN) elektrodą wolframową torowaną WT20 o średnicy 2,4 mm wg parametrów umożliwiających uzyskanie wtopienia o głębokości ok. $3 \mathrm{~mm}$ (tabl. III). Przetopione blachy przecięto w odległości $15 \mathrm{~mm}$ od czoła próbki, tj. w połowie długości ściegów i wykonano zgłady metalograficzne (rys. 4).

Analiza mikrotwardości obszarów przetopień wykazała nieznaczne różnice twardości w porównaniu do materiału rodzimego. Przy modyfikacji stali proszkiem Fe uzyskano twardość na poziomie ok. $190 \mu \mathrm{HV} 0,1$, czyli o $10 \mu \mathrm{HV} 0,1$ mniejszą od twardości materiału rodzimego (tabl. IV). Dodatek węgla w postaci Karburytu nie zmienia twardości ściegów, podczas gdy węgiel w postaci CNTs powoduje wzrost twardości o ok. $25 \%$ (tabl. IV).

Obserwacje SEM (JEOL 5800 LV SEM EDX) obszaru przetopienia stali austenitycznej 1H18N9

Tablica III. Parametry przetopień wykonanych metodą TIG na powierzchni stali austenitycznej 1H18N9 (AISI 301) z nawierconymi otworami z wsadem

Table III. Parameters of 1H18N9 (AISI 301) austenitic steel surface TIG welding with filler material in the drilled holes

\begin{tabular}{|c|c|c|c|c|}
\hline 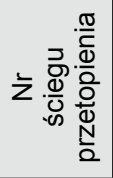 & 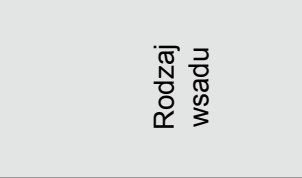 & 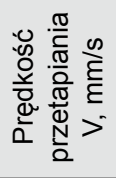 & 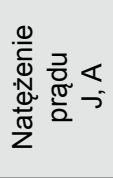 & 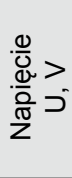 \\
\hline 1 & $100 \% \mathrm{Fe}$ & \multirow{7}{*}{2} & \multirow{7}{*}{80} & \multirow{7}{*}{12} \\
\hline 2 & $99,5 \% \mathrm{Fe}+0,5 \% \mathrm{CNTs}$ & & & \\
\hline 3 & $99,0 \% \mathrm{Fe}+1,0 \% \mathrm{CNTs}$ & & & \\
\hline 4 & $100,0 \%$ CNTs & & & \\
\hline 5 & $99,5 \% \mathrm{Fe}+0,5 \% \mathrm{KR}$ & & & \\
\hline 6 & $99,0 \% \mathrm{Fe}+1,0 \% \mathrm{KR}$ & & & \\
\hline 7 & $100,0 \% \mathrm{KR}$ & & & \\
\hline
\end{tabular}




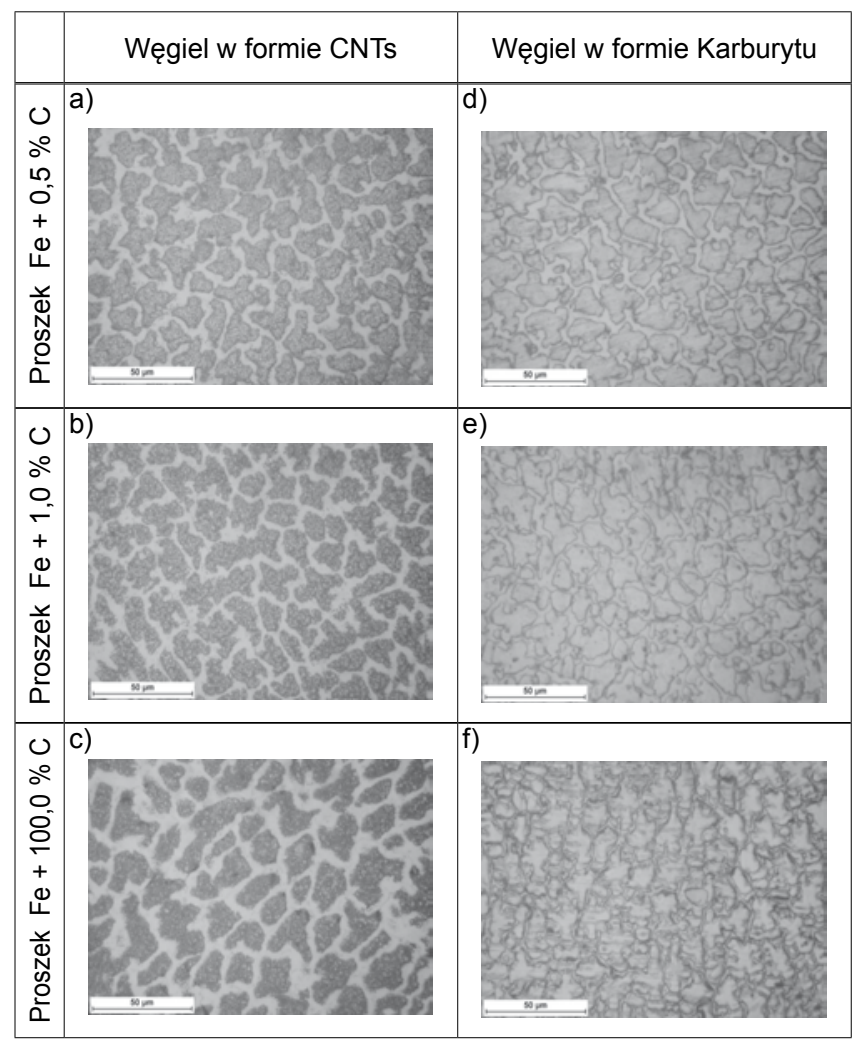

Rys. 4. Mikrostruktura obszarów przetopienia stali 1H18N9 (AIS 301) zmodyfikowanej węglem $w$ formie: $a-c)$ nanorurek węglowych, d-f) Karburytu

Fig. 4. Microstructure of weld penetration areas of steel $1 \mathrm{H} 18 \mathrm{~N} 9$ (AISI 301) modified with carbon in the form of: a-c) of carbon nanotubes, d-f) Karburytu

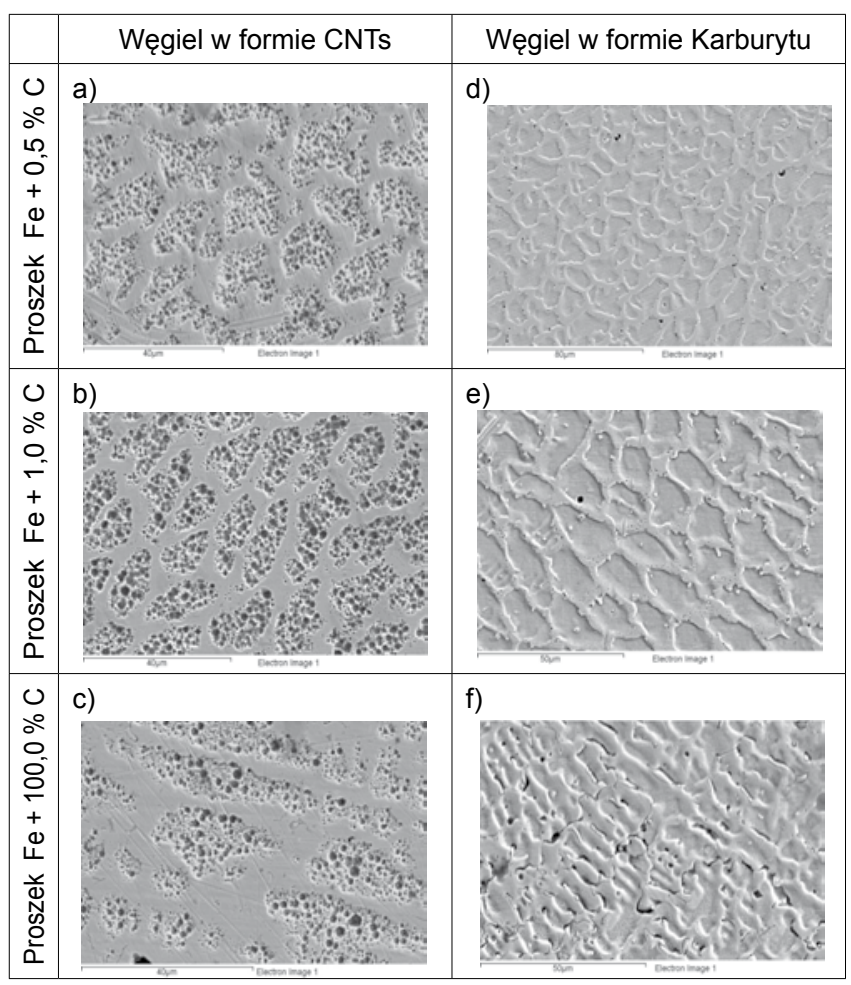

Rys. 5. Mikrostruktura obszarów przetopień stali 1H18N9 (AISI 301) zmodyfikowanej węglem w formie: a-c) nanorurek węglowych, d-f) Karburytu

Fig. 5. Microstructure of weld penetration areas of steel $1 \mathrm{H} 18 \mathrm{~N} 9$ (AISI 301) modified with carbon in the form of: a-c) of carbon nanotubes, d-f) Karburytu
(AISI 301) zmodyfikowanej nanorurkami węglowymi wykazały, że ciemne obszary, interpretowane pierwotnie (na podstawie obserwacji z wykorzystaniem mikroskopu optycznego) jako jedna $z$ faz, stanowią gęsto upakowane pęcherze o wymiarze od $50 \mathrm{~nm}$ do kilku $\mu \mathrm{m}$ (rys. 5a-c). Pęcherze te nie występują w przypadku stali modyfikowanej żelazem oraz węglem $w$ formie Karburytu (rys. 5d-f). Wysokorozdzielcza mikroskopia skaningowa pozwoliła zaobserwować wystające z pę-

Tablica IV. Wartość średnia pomiarów mikrotwardości HV0,1

Table IV. The average value of microhardness HV0,1

\begin{tabular}{|c|c|c|c|c|c|c|}
\hline \multirow[b]{2}{*}{$\begin{array}{c}\text { Przeto- } \\
\text { piona stal } \\
1 \mathrm{H} 18 \mathrm{N9} \\
\text { (AISI 301) }\end{array}$} & \multicolumn{6}{|c|}{$\begin{array}{c}\text { Przetopiona stal 1H18N9 (AISI 301) } \\
\text { zmodyfikowana proszkiem }\end{array}$} \\
\hline & 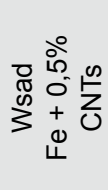 & 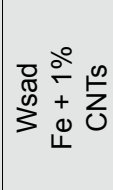 & 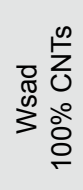 & 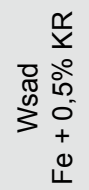 & 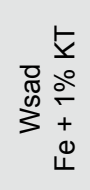 & 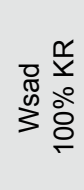 \\
\hline 200 & 207,6 & 282,7 & 254,3 & 187,3 & 176,9 & 200,5 \\
\hline
\end{tabular}

Tablica V. Parametry analizy fazowej XRD (Philips APD X'Pert PW 3020)

Table V. The XRD phase analysis parameters (Philips APD X'Pert PW 3020)

\begin{tabular}{|c|c|}
\hline Parametr & Wartość \\
\hline Kąt początkowy $2 \theta,^{\circ}$ & 20,0 \\
\hline Kąt końcowy $2 \theta,^{\circ}$ & 100,0 \\
\hline Skok kątowy $2 \theta,^{\circ}$ & 0,02 \\
\hline Czas zliczania impulsów w 1 pozycji, s & 6,0 \\
\hline Szczelina formująca wiązkę, ${ }^{\circ}$ & 0,5 \\
\hline Szczelina wyjściowa, mm & 0,2 \\
\hline Napięcie, kV & 40,0 \\
\hline Natężenie prądu, mA & 40,0 \\
\hline Obrót próbki, obr/s & 2,0 \\
\hline
\end{tabular}
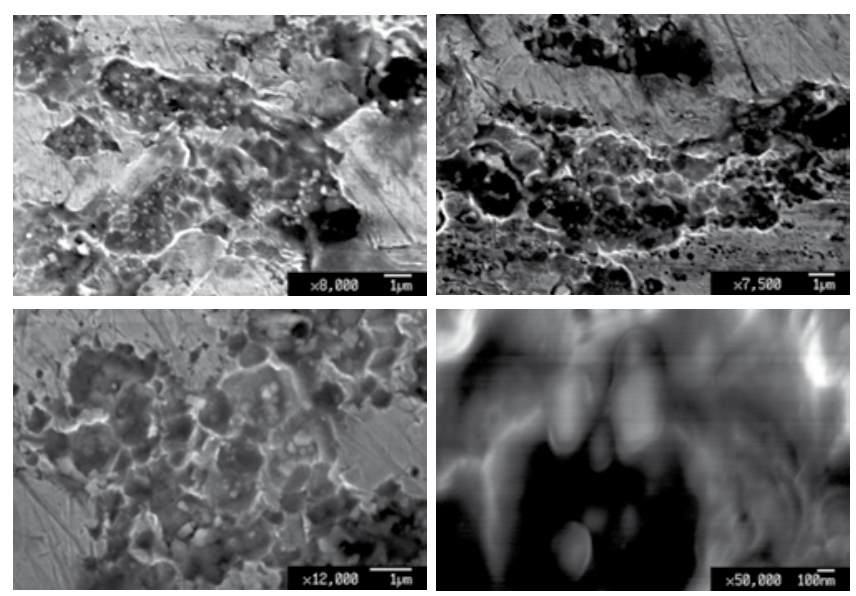

Rys. 6. Cząsteczki o wymiarze $100 \div 300 \mathrm{~nm}$ wypełniające mikropęcherze w obszarze przetopienia stali austenitycznej 1H18N9 (AISI 301) zmodyfikowanej proszkiem $100 \%$ CNTs, (rys. 4c i 5c)

Fig. 6. Micropores filling particles of $100 \div 300 \mathrm{~nm}$ size in the weld penetration of $1 \mathrm{H} 18 \mathrm{~N} 9$ austenitic steel (AISI 301) 100\% CNTs powder modified (fig. 4c and 5c)

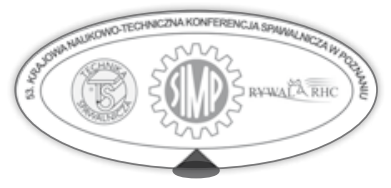




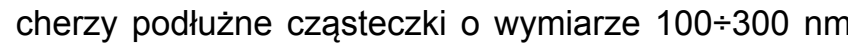
(rys. 6). W celu identyfikacji tej fazy przeprowadzono rentgenowską analizę fazową z wykorzystaniem dyfraktometru Philips APD X'Pert PW 3020. Dyfraktogramy materiału rodzimego oraz obszaru przetopienia stali austenitycznej 1H18N9 zmodyfikowanej proszkiem $100 \%$ CNTs sporządzono przy parametrach jak w tablicy $\mathrm{V}$.

Dyfraktogram otrzymany dla stali 1H18N9 (AISI 301) odpowiada stali austenitycznej (Fe-Cr-Ni) (rys. 7a, tabl. VI). Jeden dodatkowy pik o bardzo małej intensywności przy $2 \theta=39,0527^{\circ}$ można potraktować jako zakłócenie. Dyfraktogram otrzymany dla obszaru przetopienia stali austenitycznej 1H18N9 (AISI 301 ) zmodyfikowanej proszkiem $100 \%$ CNTs jest identyczny z dyfraktogramem materiału rodzimego, pomimo wyraźnie odmiennej mikrostruktury. Dodatkowy pik o bardzo małej intensywności przy $2 \theta=29,4355^{\circ}$ analogicznie jak w przypadku MR można potraktować jako zakłócenie, (rys. 7b, tabl. VII). Nie zaobserwowano pików przy $2 \theta=26^{\circ}, 2 \theta=42,4^{\circ}$ i $2 \theta=77,7^{\circ}$, które mogłyby świadczyć o obecności nanorurek węglowych.

Niemal identyczne mikrostruktury obszarów przetopienia stali austenitycznej 1H18N9 (AISI 301) zmodyfikowanej proszkami o różnym udziale nanorurek węglowych, tj.: Fe $+0,5 \%$ CNTs, Fe $+1 \%$ CNTs oraz 100\% CNTs, pozwalają przypuszczać, że w czasie przetapiania łukowego TIG próbek z wsadem o największym udziale CNTs znaczna część nanorurek węglowych uległa wypaleniu i tylko niewielka ich część wzięła udział w modyfikacji struktury stali (rys. 4a-c i 5a-c). Bardzo mały rozmiar wykorzystanych nanorurek wę- a)

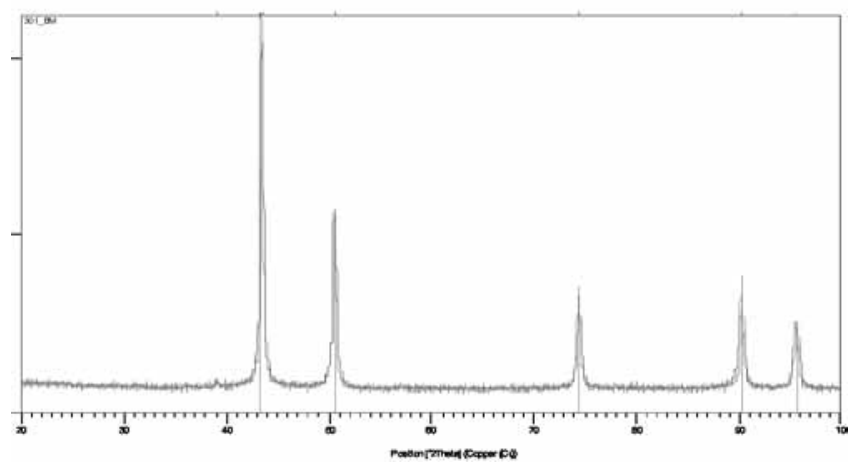

b)

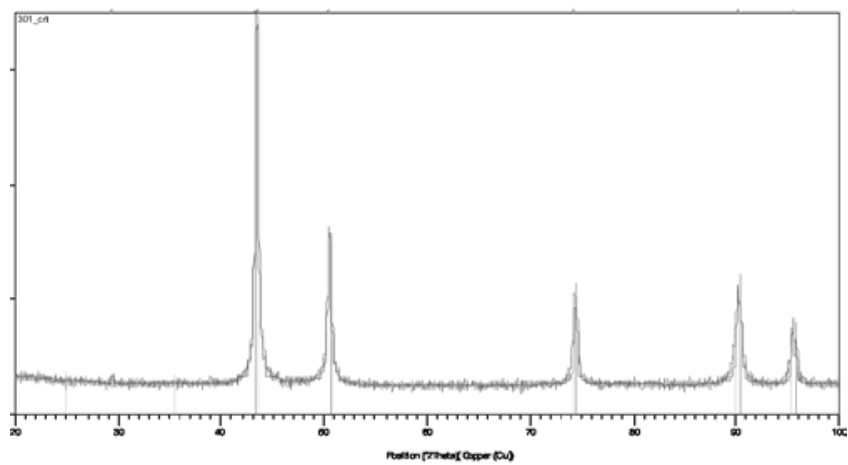

Rys. 7. Dyfraktogram otrzymany dla: a) stali austenitycznej $1 \mathrm{H} 18 \mathrm{~N} 9$ (AISI 301), b) stali austenitycznej 1H18N9 (AISI 301) zmodyfikowanej proszkiem $100 \%$ CNTs, analiza wg tabl. V (Philips APD X'Pert PW 3020)

Fig. 7. Diffraction pattern obtained for: a) $1 \mathrm{H} 18 \mathrm{~N} 9$ austenitic steel (AISI 301), b) 1H18N9 austenitic steel (AISI 301) 100\% powder CNTs modified, the analysis acc. to tab. V (Philips APD X'Pert PW 3020)

Tablica VI. Pozycje i natężenia pików dyfraktogramu otrzymanego dla stali austenitycznej 1H18N9 (AISI 301) (rys. 7a) Table VI. Peak positions and intensities of diffraction pattern obtained for 1H18N9 austenitic steel (AISI 301) (Fig. 7a)

\begin{tabular}{|c|c|c|c|c|c|c|}
\hline Pozycja, ${ }^{\circ} 2 \theta$ & Max. cts & FWHM, ${ }^{\circ} 2 \theta$ & d-spacing, $\AA$ & Rel. Int,. \% & Tip width, ${ }^{\circ} 2 \theta$ & Faza* \\
\hline 39.0527 & 24.55 & 0.2362 & 2.30653 & 0.21 & 0.2834 & - \\
\hline 43.4056 & 11834.53 & 0.1968 & 2.08479 & 100.00 & 0.2362 & \multirow{5}{*}{$\begin{array}{l}\mathrm{Fe} \\
\mathrm{Cr} \\
\mathrm{Ni}\end{array}$} \\
\hline 50.5055 & 3185.22 & 0.2755 & 1.80711 & 26.91 & 0.3306 & \\
\hline 74.3729 & 853.97 & 0.3149 & 1.27552 & 7.22 & 0.3779 & \\
\hline 90.1956 & 1077.74 & 0.1968 & 1.08841 & 9.11 & 0.2362 & \\
\hline 95.5174 & 540.68 & 0.3840 & 1.04049 & 4.57 & 0.4608 & \\
\hline
\end{tabular}

Tablica VII. Pozycje i natężenia pików dyfraktogramu otrzymanego dla stali austenitycznej 1H18N9 (AISI 301) zmodyfikowanej proszkiem $100 \%$ CNTs (rys. $7 \mathrm{~b}$ )

Table VII. Peak positions and intensities of diffraction pattern obtained for 1H18N9 austenitic steel (AISI 301) 100\% powder CNTs modified (fig. 7b)

\begin{tabular}{|c|c|c|c|c|c|c|}
\hline Pozycja ${ }^{\circ} 2 \theta$ & Max. cts & FWHM, $^{\circ} 2 \theta$ & d-spacing, $\AA$ & Rel. Int., $\%$ & Tip width, $^{\circ} 2 \theta$ & Faza* $^{*}$ \\
\hline 29.4355 & 22.31 & 0.1574 & 3.03450 & 0.31 & 0.1889 & - \\
\hline 43.4496 & 7135.87 & 0.2362 & 2.08278 & 100.00 & 0.2834 & 0.3306 \\
\hline 50.5160 & 1499.58 & 0.2755 & 1.80676 & 21.01 & 0.2362 & $\mathrm{Fe}$ \\
\hline 74.3599 & 608.28 & 0.1968 & 1.27571 & 8.52 & 0.3456 & $\mathrm{Ni}$ \\
\hline 90.2075 & 649.61 & 0.2880 & 1.08740 & 9.10 & 0.2304 & \\
\hline 95.5237 & 360.80 & 0.1920 & 1.04044 & 5.06 & & \\
\hline
\end{tabular}



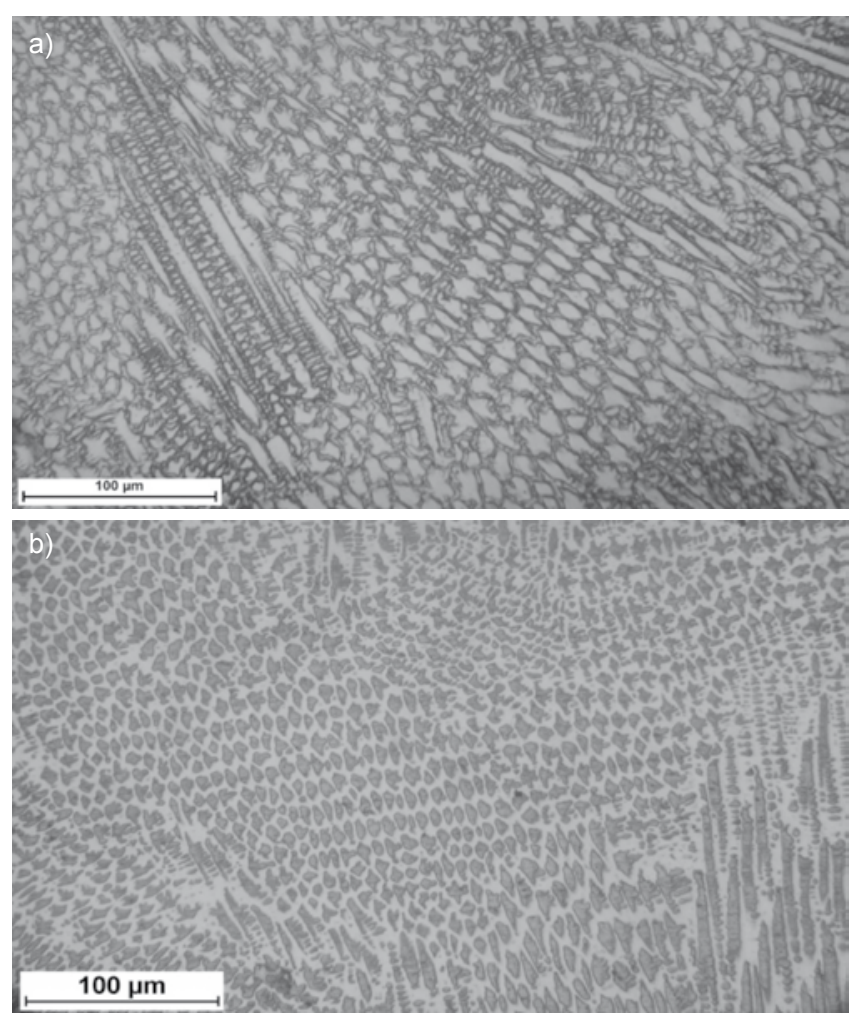

Rys. 8. Mikrostruktura: a) przetopionej stali 1H18N9 (AISI 301), ścieg 1, b) napoiny wykonanej $z$ wykorzystaniem drutu proszkowego wypełnionego $100 \%$ Fe, ścieg 2 (tabl. VIII)

Fig. 8. Microstructure: a) the melted $1 \mathrm{H} 18 \mathrm{~N} 9$ steel (AISI 301), bead 1, b) the padding weld made with the use of $100 \%$ Fe cored wire, bead 2 (tab. VIII)

glowych (średnica ok. 9,5 nm), przypadkowa orientacja w osnowie oraz niewielki udział wagowy mogą uniemożliwić wykrycie CNTs podczas badań XRD. Tym samym brak możliwości jednoznacznego określenia natury cząstek wypełniających pęcherze pozwala jedynie przypuszczać, że stanowią one wiązki nanorurek węglowych bądź nanocząsteczki powstałe w wyniku ich rozkładu.

Procedura druga. W celu wprowadzenia nanorurek węglowych do jeziorka ciekłego metalu wykonano materiał dodatkowy w postaci drutu z rdzeniem proszkowym. Koszulkę ze stali niskowęglowej o średnicy
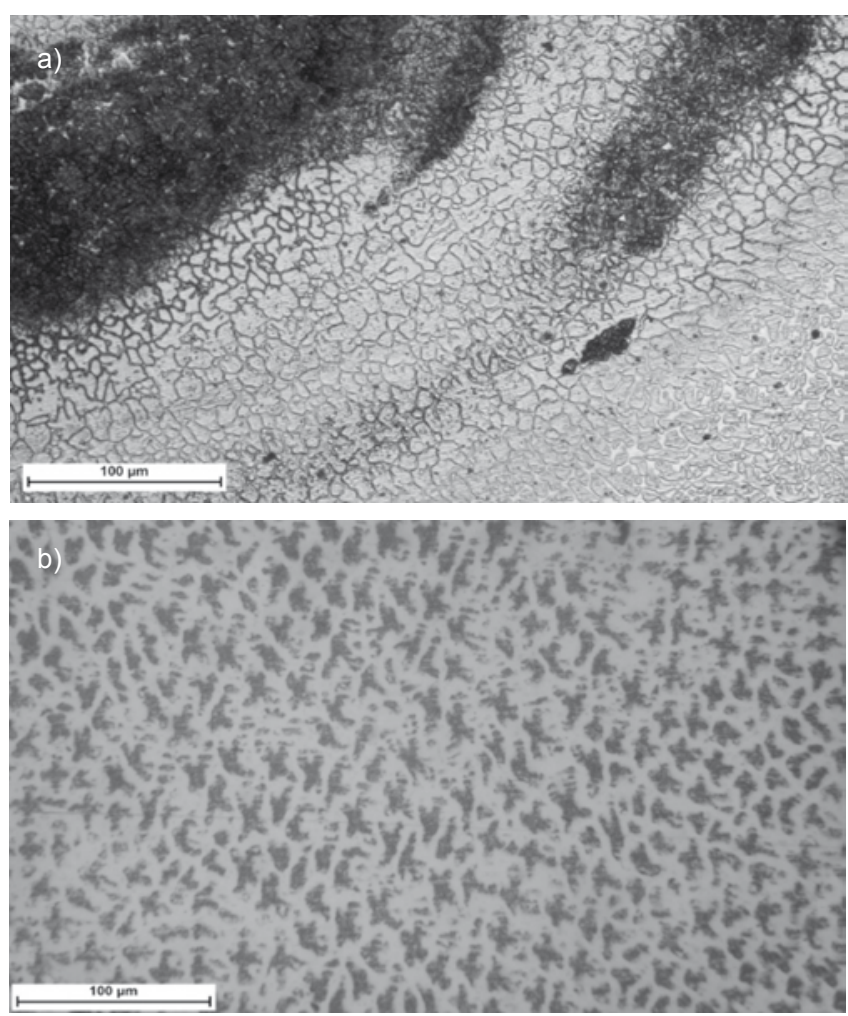

Rys. 9. Mikrostruktura napoiny wykonanej z wykorzystaniem drutu proszkowego wypełnionego: a) $\mathrm{Fe}+0,5 \%$ CNTs, ścieg 3 , b) $\mathrm{Fe}+1,0 \%$ CNTs, prędkość przetapiania $3 \mathrm{~mm} / \mathrm{s}$, ścieg 4 (tabl. VIII) Fig. 9. Microstructure of the padding weld deposit made with the use of cored wire: a) $\mathrm{Fe}+0.5 \% \mathrm{CNTs}$, bead 3, b) Fe $+1.0 \%$ CNTs, bead 4 , The welding speed of $3 \mathrm{~mm} / \mathrm{s}$ (tab. VIII)

1,6 mm wypełniono nanorurkami węglowymi, żelazem oraz ich mieszankami (tabl. VIII). Następnie wykonano napoiny metodą TIG (CASTOTIG 2002, CASTOLIN), stosując parametry jak w tablicy VIII. Blachę przecięto $\mathrm{w}$ odległości $15 \mathrm{~mm}$ od czoła próbki, tj. w połowie długości ściegów i wykonano zgłady metalograficzne

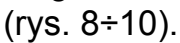

Struktura i wielkość ziaren ściegów wykonanych bez materiału dodatkowego i z materiałem dodatkowym w postaci drutów z rdzeniem proszkowym są podobne, jednakwdrugimprzypadkuwidocznajestznacznaniejednorodność wynikająca z niedostatecznego wymieszania

Tablica VIII. Parametry przetopień wykonanych metodą TIG na powierzchni stali austenitycznej 1H18N9 (AISI 301) z wykorzystaniem materiału dodatkowego w postaci drutu $\mathrm{z}$ rdzeniem proszkowym

Table VIII. Parameters of 1H18N9 (AISI 301) austenitic steel surface TIG welding with filler material in the form of cored wire

\begin{tabular}{|c|c|c|c|c|}
\hline Nr ściegu przetopienia & Rodzaj wsadu & Prędkość przetapiania $\mathrm{V}, \mathrm{mm} / \mathrm{s}$ & Natężenie prądu I, A & Napięcie U, V \\
\hline 1 & brak & \multirow{4}{*}{3} & \multirow{8}{*}{80} & \multirow{8}{*}{12} \\
\hline 2 & $100 \% \mathrm{Fe}$ & & & \\
\hline 3 & $\mathrm{Fe}+0,5 \% \mathrm{CNTs}$ & & & \\
\hline 4 & $\mathrm{Fe}+1 \% \mathrm{CNTs}$ & & & \\
\hline 5 & brak & \multirow{4}{*}{4,5} & & \\
\hline 6 & $100 \% \mathrm{Fe}$ & & & \\
\hline 7 & $\mathrm{Fe}+0,5 \% \mathrm{CNTs}$ & & & \\
\hline 8 & $\mathrm{Fe}+1 \% \mathrm{CNTs}$ & & & \\
\hline
\end{tabular}

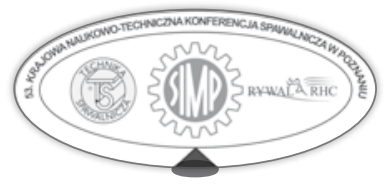



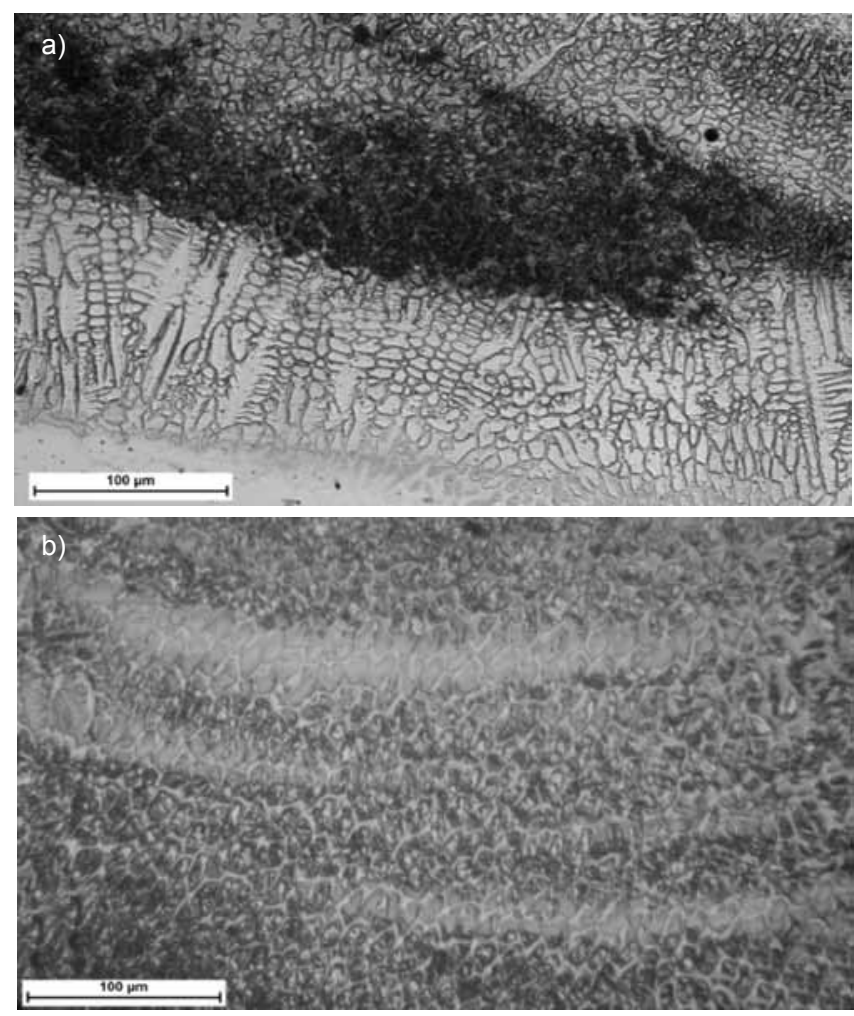

Rys. 10. Mikrostruktura napoiny wykonanej z wykorzystaniem drutu proszkowego wypełnionego: a) $\mathrm{Fe}+0,5 \%$ CNTs, ścieg 7, b) $\mathrm{Fe}$ $+1,0 \%$ CNTs, ścieg 8 , prędkość przetapiania $4,5 \mathrm{~mm} / \mathrm{s}$ (tabl. VIII) Fig. 10. Microstructure of the padding weld made with the use of cored wire: a) $\mathrm{Fe}+0,5 \% \mathrm{CNTs}$, bead 7, b) $\mathrm{Fe}+1,0 \%$ CNTs. bead 8 , The welding speed of $4,5 \mathrm{~mm} / \mathrm{s}$ (tab. VIII)

spoiwa z materiałem rodzimym (jasne i ciemne obsza-

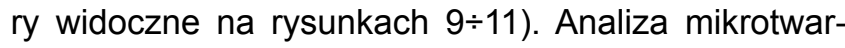
dości ściegów wykonanych metodą TIG przy stałych parametrach procesu wykazała znaczną niejednorodność właściwości obszaru przetopienia (tabl. IX). W jasnych obszarach przetopień zaobserwowano 30\% wzrost twardości w porównaniu do materiału rodzimego, podczas gdy w ciemnych obszarach twardość dochodzi do $300 \%$ twardości materiału rodzimego (rys. 11). Największy wzrost twardości odnotowano w przypadku zastosowania drutów z rdzeniem proszkowym o największym udziale nanorurek węglowych, tj. Fe + 1\% CNTs, ściegi 4 i 8 (tabl. VIII).

Procedura trzecia. W większości przypadków wytwarzania kompozytów MM-CNT materiał wyjściowy do dalszej przeróbki powstaje mieszania nanorurek węglowych z proszkami metalicznymi za pomocą młynów kulowych [25]. Niektóre rozwiązania wykorzystują dyspersję w ciekłym medium dzięki mieszaniu ultradźwiękowemu [26], rozpylanie i suszenie zawiesiny nanorurek [27], bądź syntezę CNTs bezpośrednio na cząsteczkach proszku metalu stanowiącego osnowę kompozytu [28]. Badania wstępne wykazały, że nanorurki węglowe $w$ formie czystego proszku, jak i mieszanki z proszkami metalicznymi są wydmuchiwane z obszaru przetapiania nawet przy najmniejszym dopuszczalnym przepływie gazu osłonowego. Dlatego też w trzeciej procedurze wprowadzania CNTs do jeziorka ciekłego metalu zaproponowano bezpośrednią

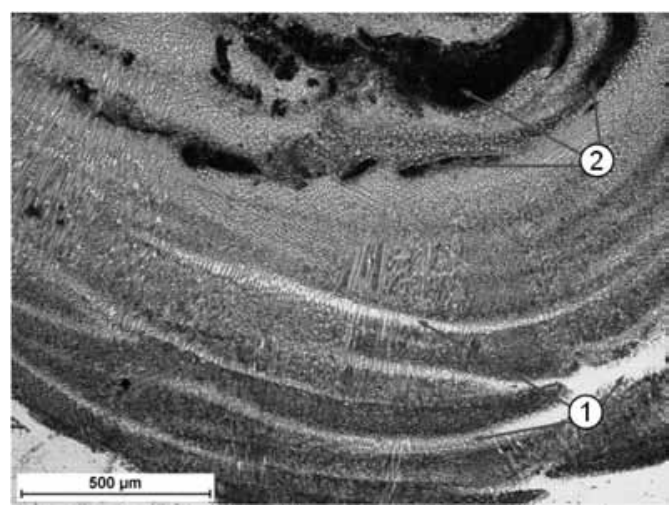

Rys. 11. Strefy niejednorodnego wymieszania spoiwa $z$ materiałem rodzimym: 1 - jasne obszary o niewielkiej twardości, 2 - ciemne obszary o wysokiej twardości

Fig. 11. Non-homogeneous zones of weld material and base material mixing: 1 - bright areas with low hardness, 2 - the dark areas with high hardness

Tablica IX. Wartość średnia pomiarów mikrotwardości HV0,1 Table IX. The average value of microhardness HV0,1

\begin{tabular}{|c|c|c|c|c|c|c|c|}
\hline \multicolumn{3}{|c|}{ Prędkość przetapiania 3 mm/s } & \multicolumn{4}{c|}{ Prędkość przetapiania 4,5 mm/s } \\
\hline Ścieg 1 & Ścieg 2 & Ścieg 3 & Ścieg 4 & Ścieg 5 & Ścieg 6 & Ścieg 7 & Ścieg 8 \\
\hline 196,5 & 200,3 & 351,4 & 454,2 & 192,6 & 210,3 & 361,3 & 580,9 \\
\hline
\end{tabular}

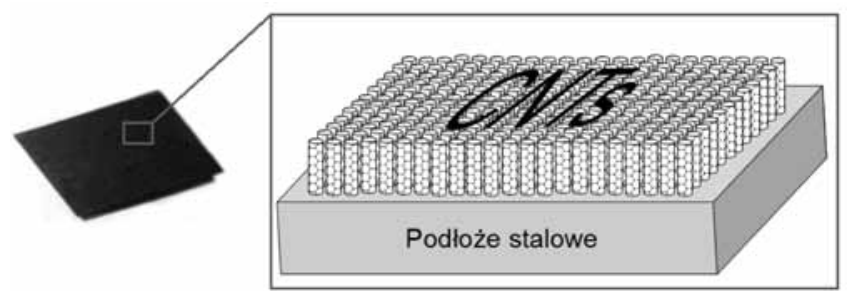

Rys. 12. Płytka stalowa z uzyskaną na drodze syntezy CVD warstwą nanorurek węglowych ułożonych prostopadle do podłoża

Fig. 12. Steel plate obtained by the CVD synthesis of carbon nanotubes layer arranged perpendicular to the ground
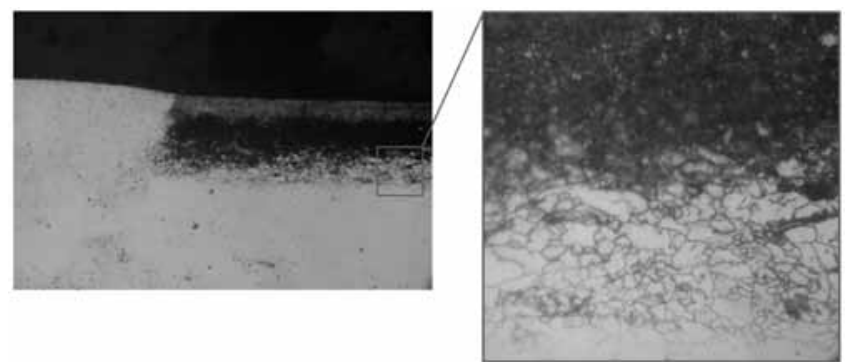

Rys. 13. Zmiana mikrostruktury analizowanej stali spowodowana warunkami syntezy CVD

Fig. 13. Change of microstructure of analyzed steel caused by the conditions of CVD synthesis

syntezę nanorurek węglowych na powierzchni płytek stalowych, co gwarantuje ich dobrą przyczepność do podłoża (rys. 12).

Do syntezy wielościennych nanorurek węglowych na podłożu ze stali austenitycznej wykorzystano reaktor CVD zaprojektowany przez zespół naukowy z Department of Materials Science and Metallurgy, University of Cambridge oraz substraty $w$ formie mieszanki ferrocen/toluen. Ferrocen, którego temperatura 
parowania wynosi $170^{\circ} \mathrm{C}$, został wykorzystany jako źródło katalizatora (żelazo) jak i węgla. Toluen, którego temperatura parowania to $110^{\circ} \mathrm{C}$, został zastosowany jako rozpuszczalnik dla ferrocenu i główny składnik węgla w procesie syntezy. W czasie syntezy uzyskano płytki $z$ warstwą wierzchnią $w$ formie uporządkowanych nanorurek węglowych o prostopadłej orientacji względem stalowego podłoża, które następnie przetopiono laserem włóknowym HPFL (SPI200C firmy SPI) oraz łukiem mikroplazmowym (EUTRONIC GAP 2001DC, CASTOLIN).

\section{Wnioski}

Przeprowadzone badania pozwalają stwierdzić, że przetapianie blach $z$ otworami wypełnionymi proszkiem o ściśle określonym składzie chemicznym (procedura pierwsza) stanowi najlepszą metodę wprowadzania nanorurek węglowych do jeziorka ciekłego metalu. Brak czynników zakłócających, takich jak obecność pierwiastków stopowych w koszulce drutu spawalniczego (wykorzystywanego w procedurze drugiej) decyduje o skuteczności metody i ułatwia optymalizację parametrów procesu. Metoda trzecia, ze względu na niekorzystną zmianę struktury analizowanej stali, wymaga modyfikacji. Rozwiązaniem problemu może być synteza na podłożu kwarcowym, po której nastąpi przeniesienie „dywaników” na powierzchnię niezmodyfikowanej stali.

Wykorzystując procedurę pierwszą wykazano, że wprowadzając do jeziorka ciekłego metalu analogiczne ilości węgla w formie nanorurek i Karburytu,
Zaleta opracowanej metody jest niewrażliwość na działanie gazu osłonowego (dzięki dobrej przyczepności CNTs do podłoża), jednak długi czas wytrzymania (ok. 4 h) w wysokiej temperaturze pieca reakcyjnego (ok. $760^{\circ} \mathrm{C}$ ) w obecności produktów odparowania mieszanki ferrocen/toluen $(\mathrm{C}, \mathrm{H}, \mathrm{Fe})$ doprowadził do zmian strukturalnych podłoża, które uniemożliwiają jednoznaczną ocenę wpływu CNTs na strukturę i właściwości stali (rys. 14). można uzyskać ściegi o odmiennej strukturze i twardości. Potwierdza to zasadność dalszych badań z wykorzystaniem nanorurek węglowych jako modyfikatora stali, a także innych metali i ich stopów. Opracowane metody wprowadzania nanorurek węglowych do jeziorka ciekłego metalu należy wykorzystać w badaniu ich stabilności chemicznej oraz strukturalnej w ciekłych stopach przy różnych metodach przetapiania. W czasie analizy XRD nie zaobserwowano pików, które mogłyby świadczyć o obecności nanorurek węglowych w analizowanych ściegach. Ze względu na wysoką temperaturę towarzyszącą przetapianiu stali austenitycznej, nanorurki węglowe najprawdopodobniej uległy rozkładowi. W związku z tym w badaniach nad zastosowaniem CNTs jako składnika umacniającego materiały kompozytowe zaleca się wybór metali bądź też stopów o niższej temperaturze topnienia od analizowanej stali austenitycznej.

\section{Literatura}

[1] Agrawal A.: Carbon Nanotubes: Reinforced Metal Matrix Composites, CRC Press ISBN:1439811490, 2010.

[2] Bakshi S. at al.: Carbon nanotube reinforced metal matrix composites - a review, International Materials Reviews, Vol. 55 No. 1/ 2010, s. 41-64.

[3] Coleman J., at al.: Small but strong: A review of the mechanical properties of carbon nanotube-polymer composites, Carbon, Vol. 44, Iss. 9, pp. 1624-1652, 2006.

[4] Neubauer E., at al.: Potential and challenges of metal-matrix-composites reinforced with carbon nanofibers and carbon nanotubes, Composites Science and Technology, Vol. 70, Iss. 16, 31, s. 2228-2236, 2010.

[5] Barai P., Weng G.: A theory of plasticity for carbon nanotube reinforced composites, International Journal of Plasticity 27, s. 539-559, 2011.

[6] He X., at al.: Buckling analysis of multi-walled carbon nanotubes: a continuum model accounting for van der Waals interaction, Journal of Mechanics and Physics of solids 53, pp. 303-326, 2005.

[7] Tan H., at al.: The effect of van der Waals-based interface cohesive law on carbon nanotube-reinforced composite materials, Composites Science and Technology, Vol. 67, Iss. 14, s. 2941-2946, 2007.
[8] Zeng X., at al.: A new technique for dispersion of carbon nanotube in a metal melt, Materials Science and Engineering: A, Vol. 527, Iss. 20, 25, pp. 5335-5340, 2010.

[9] Bakshi S., Batista R., Agarwal A.: Quantification of carbon nanotube distribution and property correlation in nanocomposites, Composites Part A: Applied Science and Manufacturing, Vol. 40, Iss. 8, s. 1311-1318, 2009.

[10] Deng C., at al.: Processing and properties of carbon nanotubes reinforced aluminum composites, Materials Science and Engineering A 444, s. 138-145, 2007.

[11] Liao J., Tan M.: Mixing of carbon nanotubes (CNTs) and aluminum powder for powder metallurgy use, Powder Technology, Vol. 208, Iss. 1, s. 42-48, 2011.

[12] Wu Y., Kim G.: Carbon nanotube reinforced aluminum composite fabricated by semi-solid powder processing, Journal of Materials Processing Technology, Vol. 211, Iss. 8, s. 13411347, 2011.

[13] Liao J., at al.: Carbon nanotube evolution in aluminum matrix during composite fabrication process, Materials Science Forum, Vol. 690 (2011), s. 294-297, 2011.

[14] Kim Ch., at al.: Strengthening of copper matrix composites by nickel-coated single-walled carbon nanotube reinforcements, Synthetic Metals, Vol. 159, Iss. 5-6, s. 424-429, 2009. 
[15] Cho S., at al.: Multiwalled carbon nanotubes as a contributing reinforcement phase for the improvement of thermal conductivity in copper matrix composites, Scripta Materialia, Vol. 63, Iss. 4, s. 375-378, 2010.

[16] Uddin S., at al.: Effect of size and shape of metal particles to improve hardness and electrical properties of carbon nanotube reinforced copper and copper alloy composites, Composites Science and Technology, Vol. 70, Iss. 16, s. 2253-2257, 2010

[17] Kondoh K., at al.: Microstructural and mechanical analysis of carbon nanotube reinforced magnesium alloy powder composites, Materials Science and Engineering: A, Vol. 527, Iss. 16-17, s. 4103-4108, 2010,

[18] Feng Y., Yuana H., Zhanga M.: Fabrication and properties of silver-matrix composites reinforced by carbon nanotubes, Materials Characterization, Vol. 55, Iss. 3, s. 211-218, 2005.

[19] Naia S., Weib J., Gupta M.: Improving the performance of lead-free solder reinforced with multi-walled carbon nanotubes, Materials Science and Engineering: A, Volume 423, Issues 1-2, s. 166-169, 2006.

[20] Kondoh K., at al.: Characteristics of powder metallurgy pure titanium matrix composite reinforced with multi-wall carbon nanotubes, Composites Science and Technology, Vol. 69, Iss. 7-8, pp. 1077-1081, 2009.

[21] Li Q., Rottmaira Ch., Singera R.: CNT reinforced light metal composites produced by melt stirring and by high pressure die casting, Composites Science and Technology, Volume 70, Issue 16, s. 2242-2247, 2010.
[22] Uozumi H., at at.: Fabrication process of carbon nanotube/ light metal matrix composites by squeeze casting, Materials Science and Engineering: A, Vol. 495, Iss. 1-2, s. 282-287, 2008.

[23] Zhou S., at al.: Fabrication and tribological properties of carbon nanotubes reinforced $\mathrm{Al}$ composites prepared by pressureless infiltration technique, Composites Part A: Applied Science and Manufacturing, Vol. 38, Iss. 2, s. 301-306, 2007.

[24] Laha T., at al.: Interfacial phenomena in thermally sprayed multiwalled carbon nanotube reinforced aluminum nanocomposite, Acta Mater. 55, s. 1059-1066, 2007.

[25] Liao J., Tan M.: Mixing of carbon nanotubes (CNTs) and aluminum powder for powder metallurgy use, Powder Technology, Vol. 208, Iss. 1, s. 42-48, 2011.

[26] Yu J., at al.: Controlling the dispersion of multi-wall carbon nanotubes in aqueous surfactant solution, Carbon, Vol. 45, Iss. 3, s. 618-623, 2007.

[27] Bakshi, S., at al.: Aluminum composite reinforced with multiwalled carbon nanotubes from plasma spraying of spray dried powders, Surf. Coat. Tech. 203, s. 1544-1554, 2009.

[28] Suttiruengwong S., Sricharussin W.: Synthesis of Stainless Steel/CNTs Nanocomposite Powders, Advanced Materials Research, Vol. 93-94, s. 181-184, 2010.
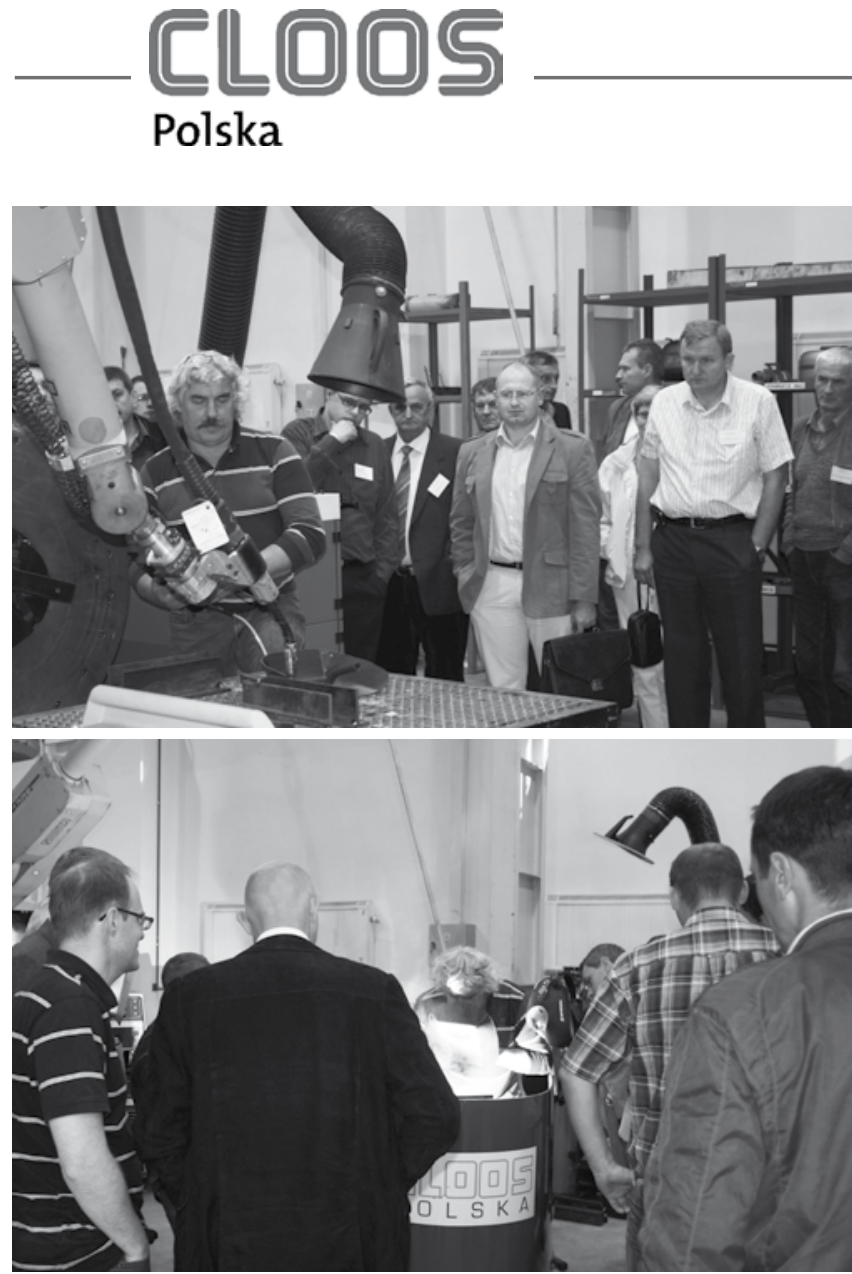

\section{Wydarzenia}

\section{Cloos Polska - 20 lat na rynku}

Kierunki rozwoju robotyzacji procesów spawalniczych - tak zatytułowane zostało seminarium, które odbyło się 28 września 2011 r. w siedzibie firmy Cloos Polska w Świdnicy. Spotkanie, w którym udział wzięło ponad 70 osób z firm i organizacji działających na rynku spawalniczym organizowane było $w$ ramach obchodów 20 rocznicy powstania firmy Cloos Polska oraz 60 rocznicy powstania Sekcji Wałbrzych SIMP.

Podczas spotkania prezentowane były zagadnienia związane z robotami serii Qirox oraz urządzeniami spawalniczymi Qineo. Szczególne zainteresowanie wzbudził wykład dotyczący spawania cylindrycznych detali wielkogabarytowych z wykorzystaniem systemu „Krokodyl”. Po sesji teoretycznej uczestnicy mieli możliwość obejrzenia praktycznych prezentacji wybranych technologii i metod spawania w tym między innymi wykorzystania sensorów w aplikacjach zrobotyzowanych, spawania technologią RapidWeld, spawania orbitalnego, znakowania przemysłowego, przyłbic spawalniczych oraz zacisków De-Sta-Co, które prezentowane były w specjalnym demonstracyjnym samochodzie pokazowym.

Wszystkim uczestnikom dziękujemy za przybycie. Cloos Polska 